\title{
ROLE OF CYTOLOGY AND COLPOSCOPY DIRECTED BIOPSY IN EVALUATION OF CLINICALLY SUSPICIOUS CERVIX
}

\author{
By
}

\section{Alaa Mohamed El-Sayed * Abd El-Halim Mohamed*, Hussien Abd El- Monem**, El-Sayed El-Desouky*, And Sileem Ahmed Sileem*}

Department of Obstetrics and Gynecology*, Department of Pathology**, Faculty of Medicine, Al-Azhar University, Assiut

E-mail: alaaelgezery2017@gmail.com

\begin{abstract}
Background: Cervical cancer is the second most common cancer among women in developing countries. Cervical cancer is a deadly disease once it reaches the invasive stages but out of all the female genital tract cancers, it is the only preventable cancer if detected in its early stages and the disease is almost $100 \%$ curable with accurate screening and early detection. Traditional screening for cervical cancer is done with papanicolaou smear test, colposcopic examination and colposcopic directed biopsy for histopathology.
\end{abstract}

Obejective: To evaluate efficacy of both cytology and colposcopy directed biopsy in evaluation of clinically suspicious cervix.

Patients and Methods: Cross sectional study on 300 patients with clinically suspicious cervix attending the outpatient Department of Obstetrics and Gynecology, at the Hospital of Al-Azher Assiut University.

Results: Pap smear had a sensitivity of $25.5 \%$ and a specificity of $87 \%$ which was attributed to the high number of false negative smears. Accuracy of pap smear was $76.7 \%$.

Colposcopy showed a sensitivity of $82 \%$ and a specificity of $81 \%$. Sensitivity was more than pap smear but specificity was less than pap smear. * Accuracy of colposcopy was found to be $81 \%$ which was comparatively more than that of pap smear (77\%).

Conclusion: It is evident that colposcopy is definitely more sensitive and accurate than pap smear. By combining pap smear with colposcopy, we can maximize the sensitivity and specificity of cancer cervix screening. Both the result of cytology and colposcopy should be compared to those of histopathology, that histopathology remain the main method of diagnosing the precursors of neoplastic cervical lesion.

Key word: Pap smear, Colposcopy, Histopathology, Suspicious cervix.

\section{INTRODUCTION}

Globally, cervical cancer comprises $12 \%$ of all cancer in women .Cervical cancer is the second most common cancer among women in developing countries (Ferlay et al., 2013).

Cervical Inter Epithelial Neoplasia (CIN) is not cancer and is usually curable if detected in its early stages with accurate screening and early detection. Most cases of CIN either remain stable or are eliminated by the person's immune system without need for intervention. However, a small percentage of cases progress to cervical cancer, typically cervical squamous cell carcinoma (SCC), if left untreated (Tainio et al., 2018). 
Traditional screening for cervical cancer is done with papanicolaou smear test, colposcopic examination and colposcopic directed biopsy for histopathology, Pap smears have formed the basis of cervical cancer screening and detection programs for many years. National cytology-based screening programs have contributed substantially to the marked decline in deaths from cervical cancer in these countries (ACOG, 2016).

Colposcopy practice includes the complete colposcopy visit from visual assessment of the cervix to biopsy sampling if indicated. Colposcopy should be viewed as a risk assessment tool that directs subsequent management with biopsies, treatment, or observation. When a lesion(s) is/are present, colposcopydirected biopsies of 2 to 4 sites are taken to establish a histopathologic diagnosis of the most severe disease present, confirm a lack of CIN/SIL/cancer, or assess for possible therapy. For low-risk women with a normal colposcopic impression, deferring biopsies may be acceptable (Wentzensen et al., 2017).

\section{PATIENTS AND METHODS}

The present cross sectional study was carried out on 300 patients, attending the outpatient Department of Obstetrics and Gynecology, at the Hospital of Al-Azhar (Assiut) University

The patients were selected by selective screening presence of either one or more of the following Criteria of clinically suspicious cervix:

- White or red patches.

- Polyp.

- hypertrophied cervix.
- Ulcers.

- Endocervical purulent discharge.

- Nodular cervix with retention cyst.

\section{Inclusion criteria:}

Women in age group of 20-60 years associated with:

1. Persistent vaginal discharge

2. Post coital bleeding

3. Cervical hypertrophy

4. Cervical erosion/ ulceration/ growth/ oozing surface

5. Contact bleeding

6. Cervix flushed with petechial spot

7. Unexplained occasional foul smelling discharge per vagina.

\section{Exclusion criteria:}

1. Pregnant or postpartum or post abortive patients.

2. Patient having any history of treatment for either cervical dysplasia or vulval warts.

3. Patient who had underwent to recent endometrial curettage, hysterosalpingography, cervical biopsy or hysterectomy.

4. Immunocompromised patients (HIV patient on corticosteroids).

\section{All patients were submitted to:}

1. Written informed consent and counseling.

2. History.

3. Physical examination.

4. Local examination of vulva. 
5. Speculum examination of cervix and vagina.

6. Cytological methods by Cervical cytology:

This is the most efficient single method of detecting premalignant and clinically unsuspected invasive cancers of the cervix. The cervical scrape was obtained under direct vision with the vaginal speculum in position (The Ayre's spatula was inserted into the os and the spatula gently bit firmly rotated through 360 degree).We used the other side of spatula to obtain the exfoliated cells from the posterior fornix .We used the cytobrush to obtain the exfoliated cells from endocervix.

The cervical mucus and cellular material on the spatula was spread evenly across a glass slide, the frosted end of which has been previously labeled in pencil with the patient's name. The slide was fixed immediately by immersing it in a solution of $95 \%$ ethanol. It was left in the fixative for 30 minutes, following which it was safely stored by dry at room temperature. Cervical smears was received in the laboratory ready-fixed and stored at room temperature. By convention a modified Papanicolaou stain was used to the slide.

\section{Colposcopic technique:}

Cervix was examined under illumination after cleaning the vagina and cervix with cotton swabs dipped in Normal Saline in order to remove the discharge.
Colposcopy directed biopsy: was taken from the abnormal site. When the acetowhite (AW) lesion was homogenous, a site near the new squamo-columnar junction (SCJ) was selected as it was more likely to harbor the worst abnormality. In heterogeneous (AW) lesion, the most suspicious area was biopsied. In cases where the new SCJ was not visualized fully as in postmenopausal women, endocervical curettage was done. The specimen was preserved in $10 \%$ formalin, labeled and sent for HPE examination.

All 300 patients underwent pap smear; colposcopic examination and colposcopy directed biopsy.

\section{Statistical analysis:}

Statistical analysis was performed using Statistical package for social science (SPSS) version 25.

The following tests were used: Descriptive analysis of the results in the form of percentage distribution for qualitative data (minimum, maximum, mean and standard deviation) calculation for quantitative data.

- P value was considered significant when $\mathrm{P} \leq 0.05$. 


\section{RESULTS}

As age increased, prevalence of CIN also increased. Prevalence of CIN was found to be high among the age group 3049 years. $2 \%$ of women had contact with more than one partner, out of them $3.9 \%$ had CIN. $3 \%$ of husbands of women in the study group had history of promiscuity. Out of them, no women had CIN. There was high prevalence of $\mathrm{CIN}$, when the duration of marriage increased and hence the duration of exposure to sexual intercourse. Among the study group, $8 \%$ were para 1 , among them 5.9 had CIN. $34 \%$ were para 2 and out of them $37.3 \%$ had CIN. 38\%were para 3, among them $39.2 \%$ had CIN. $20 \%$ were para 4 or more, among them 17.6\% had CIN (Table 1).

Table (1): Result of age, sex , duration of marriage and parity

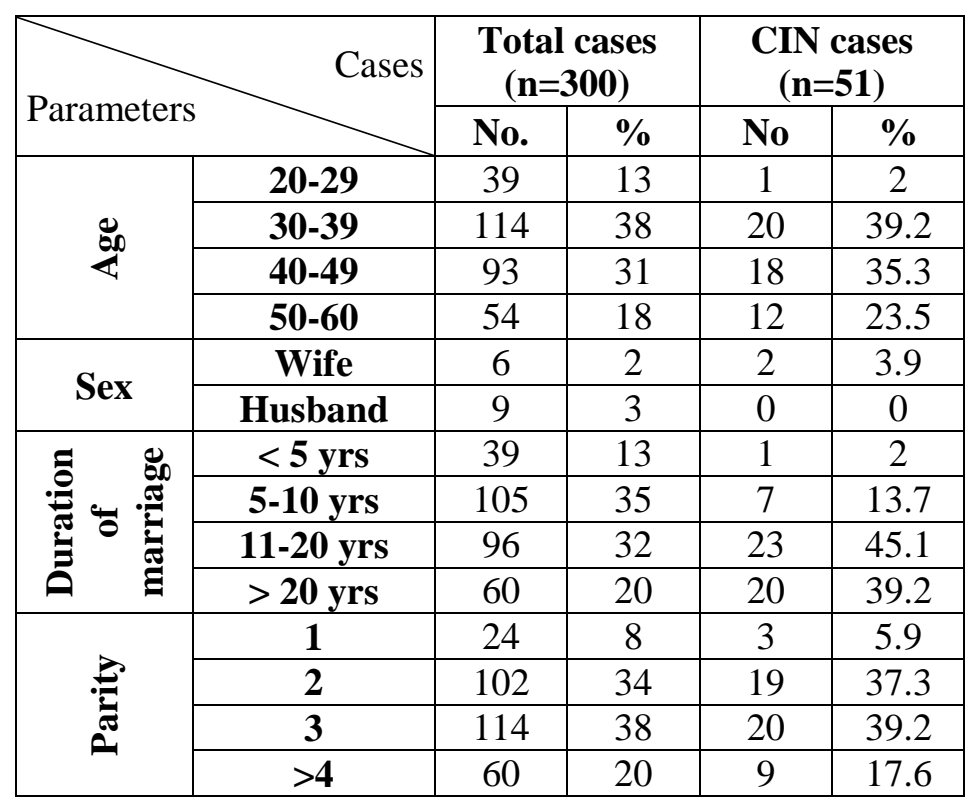

The common complaints were; white discharge and bleeding PV, which was either post coital, intermenstrual or of post-menopausal type. Out of the $56 \%$ of patients who complained of white discharge $70.6 \%$ had CIN. Of the $7 \%$ who complained of post coital bleeding $11.8 \%$ had CIN. $11 \%$ (had intermenstrual bleeding, among them $7.8 \%$ had CIN. 5\% had post-menopausal bleeding, out of them $9.8 \%$ were diagnosed to have CIN.
Other complaints included loss of weight, loss of appetite, UTI, lower abdominal pain. Among them, none had CIN. Among women with ectopy cervix, $58.8 \%$ had CIN, among those with congestion alone $11.8 \%$ had CIN, among those with hypertrophy and congestion $11.8 \%$ were found to have CIN, and in those who had hypertrophy with ectopy $17.6 \%$ were CIN positive. All polyps were benign (Table 2). 
ROLE OF CYTOLOGY AND COLPOSCOPY DIRECTED BIOPSY IN...

Table (2): Result of Complaints and Clinical appearance of cervix

\begin{tabular}{|c|c|c|c|c|c|}
\hline \multirow{2}{*}{\multicolumn{2}{|c|}{$\begin{array}{ll}\text { Parameters } & \text { Cases } \\
\end{array}$}} & \multicolumn{2}{|c|}{ Total Cases } & \multicolumn{2}{|c|}{ CIN Cases } \\
\hline & & \multirow{2}{*}{$\begin{array}{c}\text { No.300 } \\
168 \\
\end{array}$} & \multirow{2}{*}{$\begin{array}{l}\% \\
56\end{array}$} & \multirow{2}{*}{$\begin{array}{c}\text { No.51 } \\
36\end{array}$} & \multirow{2}{*}{$\begin{array}{c}\% \\
70.6\end{array}$} \\
\hline \multirow{7}{*}{ نُّ } & White discharge & & & & \\
\hline & Post coital bleeding & 21 & 7 & 6 & 11.8 \\
\hline & Intermenstrual bleeding & 33 & 11 & 4 & 7.8 \\
\hline & Post menopausal bleeding & 15 & 5 & 5 & 9.8 \\
\hline & Loss of weight/appetite & 15 & 5 & 0 & 0 \\
\hline & Others & 48 & 16 & 0 & 0 \\
\hline & Total & 300 & 100 & 51 & 100 \\
\hline \multirow{7}{*}{ 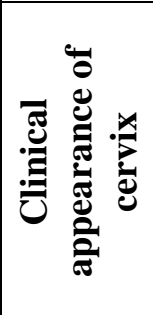 } & Atrophy & 7 & 2.5 & 0 & 0 \\
\hline & Congestion & 47 & 15.5 & 6 & 11.8 \\
\hline & Ectopy cervix & 176 & 58.6 & 30 & 58.8 \\
\hline & Hypertrophy + congestion & 19 & 6.3 & 6 & 11.8 \\
\hline & Hypertrophy + ectopy & 36 & 12 & 9 & 17.6 \\
\hline & Polyps & 15 & 5 & 0 & 0 \\
\hline & Total & 300 & 100 & 51 & 100 \\
\hline
\end{tabular}

Pap smear was done at 300 patients. $5 \%$ of smears were found to be normal, $80 \%$ showed inflammatory atypia, $10.7 \%$

Table (3): Result of Pap Smear Findings showed mild dysplasia, $4.3 \%$ showed moderate dysplasia (Table 3).

\begin{tabular}{|c|c|c|}
\hline Findings & No. of cases 300 & \% \\
\hline Normal & 15 & 5 \\
\hline Inflammatory atypia & 240 & 80 \\
\hline Mild dysplasia & 32 & 10.7 \\
\hline Moderate dysplasia & 13 & 4.3 \\
\hline Severe dysplasia & 0 & 0 \\
\hline Invasive cancer & 0 & 0 \\
\hline
\end{tabular}

Among the 300 cases studied, 29.3\% $(89 / 300)$ were diagnosed as colposcopically abnormal. Among the abnormal cases, AW areas were diagnosed in $17.7 \%$. Punctate pattern of vessels was seen in $8 \%$ of cases and mosaic pattern of vessels was diagnosed in $4 \%$ of women. And they all underwent colposcopic guided biopsy for histopathology (Table 4).

Table (4): Result of Colposcopic appearance of cervix

\begin{tabular}{|c|c|c|}
\hline Appearance & No. of cases & $\%$ \\
\hline Normal & 7 & 2.3 \\
\hline Ectopy cervix & 93 & 31 \\
\hline Inflammatory changes & 48 & 16 \\
\hline Polyps & 15 & 5 \\
\hline Leucoplakia & 6 & 2 \\
\hline Aceto White (AW) areas & 53 & 17.7 \\
\hline Punctate pattern & 24 & 8 \\
\hline Mosaic pattern & 12 & 4 \\
\hline Atypical vessels & 0 & 0 \\
\hline Unsatisfactory & 42 & 14 \\
\hline Total & 300 & 100 \\
\hline
\end{tabular}


Results of 300 cases were subjected to colposcopically directed biopsy. Majority of cases, $46.1 \%$ had chronic cervicitis, $27 \%$ had chronic cervicitis with ectopy,
$2.3 \%$ had ectopy cervix, $2.3 \%$ had epithelial hyperplasia, $5.4 \%$ had benign polyp, $10 \%$ had mild dysplasia, $7 \%$ had moderate dysplasia (Table 5).

Table (5): Result of histopathological findings(HPE)

\begin{tabular}{|c|c|c|}
\hline HPE & No. of cases300 & $\%$ \\
\hline Chronic cervicitis & 138 & 46.1 \\
\hline Chronic cervicitis + ectopy & 81 & 27 \\
\hline ectopy cervix & 7 & 2.3 \\
\hline Epithelial hyperplasia & 7 & 2.3 \\
\hline Polyp (Benign) & 16 & 5.4 \\
\hline Mild dysplasia & 30 & 10 \\
\hline Moderate dysplasia & 21 & 7 \\
\hline Severe dysplasia & 0 & 0 \\
\hline
\end{tabular}

Comparison between Pap smear and colposcopic appearance with histopathological findings were presented:
Table (6) \& (7). Also, comparison between efficacy of Pap smear and colposcopy was presented: Table (8).

Table (6): Comparison of Pap smear with Histopathological findings results

\begin{tabular}{|c|c|c|c|c|c|c|c|c|c|c|c|}
\hline \multirow{2}{*}{ Pap smears } & \multirow{2}{*}{ No. } & \multicolumn{10}{|c|}{ Histopathological findings } \\
\cline { 3 - 13 } & & \multicolumn{2}{|c|}{ Normal } & \multicolumn{2}{|c|}{ CIN I } & \multicolumn{2}{c|}{ CIN II } & \multicolumn{2}{|c|}{ CIN III } & \multicolumn{2}{|c|}{ Total } \\
\cline { 3 - 13 } & No. & $\%$ & No. & $\%$ & No. & $\%$ & No. & $\%$ & No. & $\%$ \\
\hline $\begin{array}{c}\text { Normal/ } \\
\text { inflam. } \\
\text { Atypia }\end{array}$ & 255 & 217 & 85.1 & 25 & 9.8 & 13 & 5.1 & 0 & 0 & 38 & 14.9 \\
\hline $\begin{array}{c}\text { Mild } \\
\text { Dysplasia }\end{array}$ & 32 & 27 & 84.3 & 5 & 15.7 & 0 & 0 & 0 & 0 & 5 & 15.7 \\
\hline $\begin{array}{c}\text { Moderate } \\
\text { Dysplasia }\end{array}$ & 13 & 5 & 38.5 & 0 & 0 & 8 & 61.5 & 0 & 0 & 8 & 61.5 \\
\hline $\begin{array}{c}\text { Severe } \\
\text { Dysplasia }\end{array}$ & 0 & 0 & 0 & 0 & 0 & 0 & 0 & 0 & 0 & 0 & 0 \\
\hline $\begin{array}{c}\text { Total } \\
\text { dysplastic } \\
\text { Smears }\end{array}$ & 45 & 32 & 71.1 & 5 & 11.1 & 8 & 17.8 & 0 & 0 & 13 & 28.9 \\
\hline
\end{tabular}

Table (7): Comparison of Colposcopic appearance with Histopathological Findings results

\begin{tabular}{|c|c|c|c|c|c|c|c|}
\hline \multirow{2}{*}{ Colposcopic findings } & \multirow{2}{*}{ No } & \multicolumn{5}{|c|}{ Histopathological findings } \\
\cline { 4 - 8 } & & Normal & CIN I & CIN II & CIN III & Inv. CA \\
\hline \multicolumn{2}{|c|}{ Normal / unsatisfactory } & 211 & 202 & 6 & 3 & 0 & 0 \\
\hline \multirow{2}{*}{ TW } & AW & 53 & 38 & 10 & 5 & 0 & 0 \\
\cline { 2 - 8 } & Punctate & 24 & 8 & 8 & 8 & 0 & 0 \\
\cline { 2 - 8 } & Mosaic & 12 & 1 & 6 & 5 & 0 & 0 \\
\cline { 2 - 8 } & Atypical vessels & 0 & 0 & 0 & 0 & 0 & 0 \\
\hline \multicolumn{2}{|c|}{ Total } & 300 & 249 & 30 & 21 & 0 & 0 \\
\hline
\end{tabular}


ROLE OF CYTOLOGY AND COLPOSCOPY DIRECTED BIOPSY IN...

Table (8): Efficacy of Pap smear and colposcopy

\begin{tabular}{|c|c|c|c|c|c|c|c|c|c|}
\hline Test & $\begin{array}{c}\text { True } \\
\text { positive }\end{array}$ & $\begin{array}{c}\text { False } \\
\text { positive }\end{array}$ & $\begin{array}{c}\text { True } \\
\text { negative }\end{array}$ & $\begin{array}{c}\text { False } \\
\text { negative }\end{array}$ & Sensitivity & Specificity & PPV & NPV & Accuracy \\
\hline Pap smear & 13 & 32 & 217 & 38 & 25.5 & 87 & 29 & 85 & $\mathbf{7 6 . 7 \%}$ \\
\hline Colposcopy & 42 & 47 & 202 & 9 & 82 & 81 & 47 & 96 & $\mathbf{8 1 \%}$ \\
\hline
\end{tabular}

\section{DISCUSSION}

Cervical cancer was the second most frequent cancer worldwide, However, invasive cancer of the cervix was considered to be a preventable condition as it was associated with a long pre invasive stage (CIN) making it amenable to screening and treatment.

In the present study screening was done in 300 women with unhealthy cervix, and women with dysplastic smears, with colposcopy and its results were correlated with pap smear and biopsy to determine the sensitivity and specificity of these methods in detecting CIN.

Regarding age distribution, high prevalence of CIN was found among the age group of 30-49 years with mean age of 41 years which was seen in $37 \%$ of cases. Vaidya (2012) showed in his study that CIN was more prevalent in the age group of $>35$ years.

Increasing number of sexual partners had the effect on increasing the risk of developing CIN and invasive disease. In our study, only $2 \%$ of women revealed the history of multiple sexual partners, out of which $3.9 \%$ had CIN. In our study, though $3 \%$ of males had multiple sexual partners, none of their wives developed CIN.

Sex with high risk males was also another risk factor for the development of CIN (Becker et al., 2013).
Duration of marriage and duration of exposure to sexual intercourse had a distinct role in genesis of cervical dysplasia. In our study, the prevalence of CIN was $.45 .1 \%$ in women who were married for 11-20 years, and $39.2 \%$ among women who were married for >20years. Vaidya (2012) had demonstrated the severity of underlying CIN increased with increase in the duration of marital life and hence the increase in the duration of sexual intercourse.

Regarding parity, our study showed increased prevalence of CIN among multiparous women. $37.3 \%$ were para 2 , $39.2 \%$ were para 3 and $17.6 \%$ were para 4 or more. Vaidya (2012) showed more positive cases of CIN were found with parity more than 4 . This might be attributed to hormonal and nutritional changes that occur in pregnancy, Immuno suppression during pregnancy, and cervical trauma during vaginal delivery.

Among the complaints, majority of women $(56 \%)$ complained of excessive white discharge per vagina. Among them CIN was found in $70.6 \%$.Excessive vaginal discharge playing a role in contributing to the development of CIN was also proved to be a risk factor in the study conducted by Vaidya (2012). In their study, 24\% had vaginal discharge.

Regarding the clinical appearance of cervix, the most common finding was ectopy cervix where the squamous 
epithelium of ectocervix was replaced by the columnar epithelium of endocervix. Ectopy was seen in $58.6 \%$, rest of patients showed congestion in $15.5 \%$, Hypertrophy with congestion seen in $6.3 \%$, Hypertrophy with ectopy was seen in $12 \%$ and polyp was found in $5 \%$ of cases.

CIN was found in $11.8 \%$ in women who showed congestion, $58.8 \%$ in women who showed ectopy and $11.8 \%$ in women with hypertrophy + Congestion and $17.6 \%$ in women with hypertrophy + ectopy.

Pap smear was taken for 300 cases. It showed mild dysplasia in 10, 7\%, moderate dysplasia in $4.3 \%$. Sensitivity of pap smear was found to be very low $25.5 \%$ compared to its specificity which was $87 \%$. This was attributed to the high number of false negative smears.

This data suggested that with colposcopy as a screening tool, the rate of false negative cytology could be significantly reduced. Colposcopy enhanced cervical screening particularly in women with otherwise negative smears. colposcopy Sensitivity was found to be $82 \%$ and specificity was $81 \%$. This showed a high sensitivity and a low specificity when compared to Pap smear. That was due to the high incidence of unsuspected Aceto White (AW) epithelium which might be due to inflammation, immature metaplasia, erosion and latent HPV infections. Out of 53 cases which showed AW areas without any vascular pattern only 18were confirmed by biopsy.

Colposcopy and biopsy were positive in $82.4 \%$ of cases while pap smear and biopsy were positive in only $25.4 \%$ of cases. This indicated the usefulness of colposcopy in diagnosing lesions missed by pap smear

\section{CONCLUSION}

Earlier diagnosis of CIN in adult women is a desirable goal. Invasive cancer of cervix is considered to be preventable since it is associated with a long pre - invasive stage (CIN) making it amenable to screening and treatment.

Papanicolaou (pap) smear is still primary method of screening for cervical cancer in our locality. This is due to the fact that it can detect early dysplastic cell changes and women with such abnormalities can be subjected to further diagnostic testing and treatment.

Colposcopy in general has a role in the evaluation of women with abnormal pap smears, unhealthy cervix, and seems to be more accurate in detecting CIN. Hence, primary colposcopy may be incorporated into genito urinary tract screening at first visit.

From the results of this study, it is evident that colposcopy is definitely more sensitive and accurate than pap smear. By combining pap smear with colposcopy, we can maximize the sensitivity and specificity of cancer cervix screening.

\section{RECOMMENDATIONS}

The current study recommends that cervicovaginal smears should be taken for all cases of clinically suspicious cervix, and those having abnormal Pap smear should be referred to colposcopic examination. Both the result of cytology and colposcopy should be compared to those of histopathology, that histopathology remain the main method of 
diagnosing the precursors of neoplastic cervical lesion.

\section{REFERENCES}

1. American College of Obstetricians and Gynecologists ACOG (2016): cervical cancer screening and prevention .Practice Bulletin No .168 .Obstet Gynecol, 128: e11130.

2. Becker, Adadevoh S.W and Forkouh B K (2013): Cervical cancer screening. International Journal of Gynecology and Obstetrics, 43(1): 63-4.

3. Ferlay J, Soerjomataram I, Ervik M, Dikshit R, and Eser S (2013): GLOBOKAN 2012. Cancer incidence and mortality worldwide. Lyon: International agency for Research on cancer. France, 73(8): 648-51.

4. Tainio K, Athanasiou A, Tikkinen KA, Aaltonen $\mathbf{R}$, Cárdenas $\mathbf{J}$ and GlazerLivson S, (2018): Clinical course of untreated cervical intraepithelial neoplasia grade 2 under active surveillance: systematic review and meta-analysis. BMJ, 360: k499.

5. Vaidya A (2012): Comparison of pap test among high risk and non-risk female, Kathmandu University, Medical Journal, 1(1): 8-13.

6. Wentzensen $N$, Schiffman $M$ and Silver $M$, (2017): ASCCP Colposcopy Standards: riskbased colposcopy practice. J Low Genit Tract Dis., 21:230-4. 


\section{دور الفحص الخلوي وفحص منظار عنق الرجم الموجه بسحب

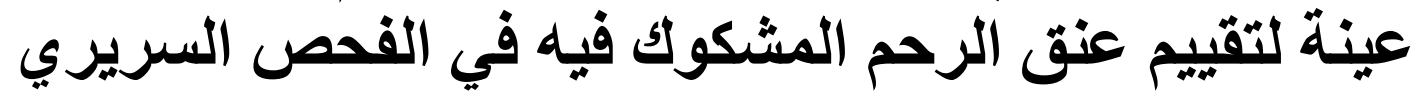 آلاء محمد السيد* عبد الحليم محمد*، حسين عبد المنعم**، السيد الدسوقي*، سليم احمد سليم* ( )}

قسم النساء التوليل** وقسم الباثولوجيا**، كلية طب الازهر، اسيوط

خلقيـة البحث: يعد سـرطان عنق الرحم ثناني أكثر أنو اع السرطان شـيو عًا بين النسـاء في الدول الناميـة،

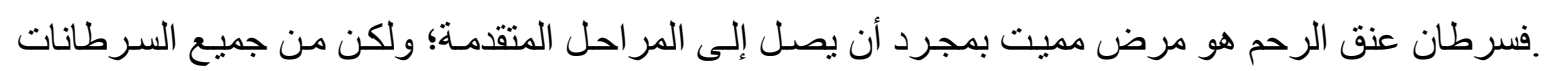

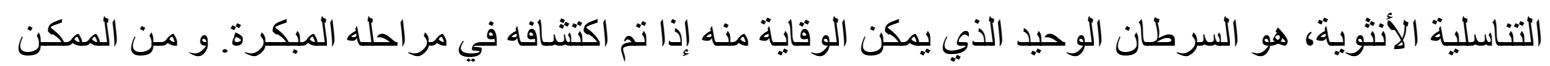

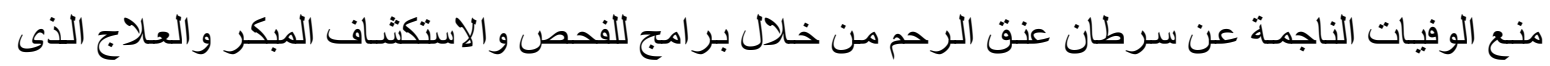

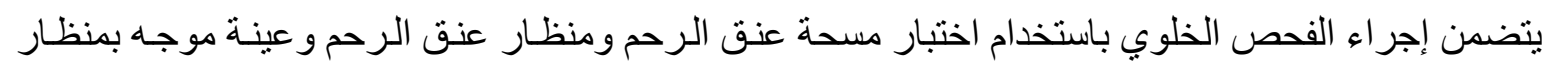

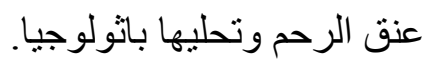

الهذف من البحث: تقييم فاعلية كلا من الفحص الخلوي ومنظار عنق الرحم الموجه بعينة للفحص الباتولوجيا

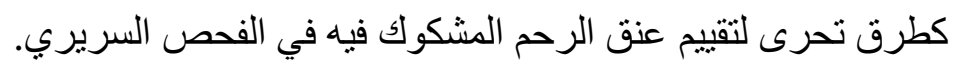

المريضـات وطرق البحث: تمت هذه الدراسة على 300 حالة من السيدات اللو اتي تم تقييمهن بفحص عنق

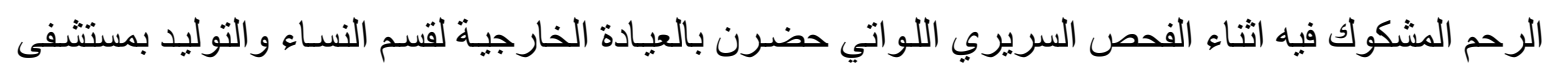

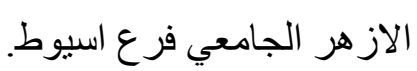

نتائج البحث: ابلغت نتيجة مسـحة عنق الرحم عن حساسية تتراوح 25.5\% ولكن تحديدها 78\%، ودقة $\% 76.7$

أبلغ منظار عنق الرحم عن حساسية تتراوح ب 82 \%، ولكن تحديدها 81 \%،ودقة تصل الى 81\%.

الاستتناج: منظار عنق الرحم أكثر حساسية دقة وسر عة في تثخيص المرض واكثر فعالية في تحديد بداية

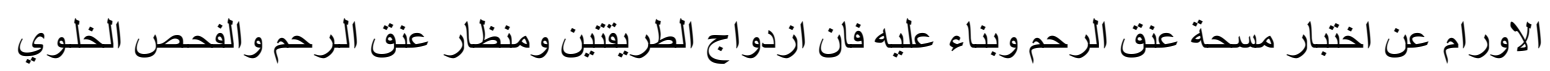

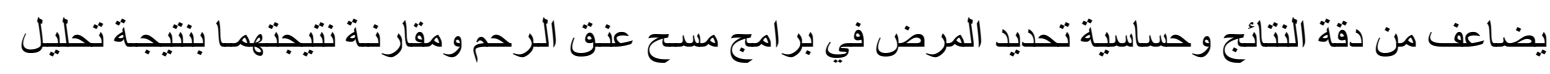

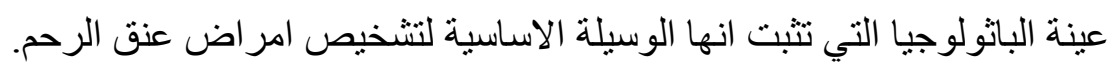

